\title{
Partitioning Evolutive Standard Base Excess Determinants in Septic Shock Patients*
}

\author{
Determinantes da Evolução do Standard Base \\ Excess em Pacientes com Choque Séptico
}

\author{
Marcelo Park', Danilo Teixeira Noritomi' ${ }^{1}$, Alexandre Toledo-Maciel', \\ Luciano Cesar Pontes de Azevedo', Vladimir Ribeiro Pizzo' ${ }^{1}$ Luiz Monteiro da Cruz-Neto ${ }^{1}$
}

\section{RESUMO}

JUSTIFICATIVA E OBJETIVOS: A acidose metabólica diagnosticada pela mensuração do standard base excess (SBE) é indicadora de maior mortalidade e sua melhora temporal é associada à maior sobrevida em pacientes críticos. O objetivo deste estudo foi esclarecer o mecanismo de variação do SBE, em pacientes com choque séptico, durante os três primeiros dias de internação na unidade de terapia intensiva (UTI), através da avaliação físico-química do equilíbrio ácido básico.

MÉTODO: Os dados foram coletados de pacientes com choque séptico a partir de um banco de dados, prospectivamente, diariamente até o terceiro dia de internação na UTI. Correlações entre o SBE e outras variáveis físico-químicas independentes foram realizadas, assim como um modelo matemático multilinear foi desenhado para revelar os determinantes independentes da variação do SBE.

RESULTADOS: A variação do SBE em pacientes sépticos nos primeiros três dias de internação na UTI foi fracamente correlacionado ao strong ion gap (SIG), lactato, albumina, creatinina e $\mathrm{PaCO}_{2}$ quando analisados individualmente. Quando analisados de forma conco-

1. Assistant Doctor - Intensive Care Unit - Emergency Department Hospital das Clínicas - University of São Paulo Medical School.

${ }^{*}$ Received from Intensive Care Unit - Emergency Department - Hospital das Clínicas - University of São Paulo Medical School - Brazil

Presented in June, 26, 2007

Accepted in October, 18, 2007

Author for correspondence:

Marcelo Park, M.D.

Rua Francisco Preto, 46, B3, Apto 64

05623-010, São Paulo, SP - Brazil

E-mail: mpark@uol.com.br

(C)Associação de Medicina Intensiva Brasileira, 2007 mitante, as variáveis albumina, strong ion difference (SIDa), SIG, $\mathrm{PaCO}_{2}$ e diurese foram independentemente associados à variação do SBE com um coeficiente de determinação de 0,866 .

CONCLUSÔES: A variação do SBE durante os três primeiros dias de internação na UTI foi resultante da interação de alguns fatores independentes como $\mathrm{PaCO}_{2}$, diurese, SIG, SIDa e albumina

Unitermos: Acidose metabólica, choque séptico, lactato, monitorização, sepse grave

\section{SUMMARY}

BACKGROUND AND OBJECTIVES: The amount of metabolic acidosis measured through the standard base excess (SBE) has been shown to be an outcome marker and its improvement has been associated with better survival. We studied the mechanism of standard base excess variation in the first three days of intensive care unit (ICU) stay through the evaluation of independent variables of physico-chemical approach.

METHODS: Data were retrieved from our prospective collected data base from patients with diagnosis of septic shock, daily up to the third day after the ICU admission. Single correlations between SBE and independent variables were performed as well as a mathematical multilinear model was built to disclose the SBE variation determinants.

RESULTS: We have shown that in septic shock patients the standard base excess variation during the first three days of ICU stay is weakly correlated to strong ion gap (SIG), lactate, creatinin and $\mathrm{PaCO}_{2}$ when individually analyzed. Analyzing concomitantly those independent variables, we built a mathematical model with a stepwise multilinear regression composed by apparent strong ion difference (SIDa), $\mathrm{SIG}, \mathrm{PaCO}_{2}$, albumin and diuresis that resulted in a $R^{2}$ coefficient of 0.866 to determine SBE variation. 
CONCLUSIONS: Variations of metabolic acidosis measured through the standard base excess in septic shock patients when analyzed until the third day after intensive care unit admission, is resultant of interaction of several independent determinants as $\mathrm{PaCO}_{2}$, diuresis, SIG, SIDa and albumin.

Key Words: lactate, metabolic acidosis, monitorization, septic shock, severe sepsis

\section{INTRODUCTION}

Base excess is the quantity of metabolic acidosis or alkalosis, defined as the amount of acid or base that must be added to a sample of whole blood in vitro in order to restore the $\mathrm{pH}$ of the sample to 7.40 while the $\mathrm{PCO}_{2}$ is held at $40 \mathrm{mmHg}^{1}$. Currently the most commonly used methodology for acquire base excess is the Van Slyke equation which takes into account the bicarbonate serum level, hemoglobin and $\mathrm{pH}^{2}$. Base excess is quite accurate in vitro, although inaccuracy has always been a problem when Van Slyke is applied in vivo, where base excess changes slightly with changes in arterial carbon dioxide partial pressure $\left(\mathrm{PaCO}_{2}\right)^{3}$. Thus, the base excess equation has been modified to standardize the effect of hemoglobin in order to improve the accuracy of base excess in vivo? The term standard base excess (SBE) has been given to this last described variable, which better quantifies the change in metabolic acid base status in multicompartment systems, highlighting the plasmatic compartment ${ }^{2,3}$.

In 1981, Dr. Peter Stewart, a Canadian physiologist, proposed a novel physico-chemical theory of acid base balance based mainly on an explicit master fourth-order polynomial equation that relates the $\mathrm{pH}$ to three independent variables: 1 . SID which is the difference of charge of all strong ions (cations - anions), 2. $\mathrm{PCO}_{2}$ and 3. Atot which is the total concentration of weak acids, represented in the human physiology by albumin and phosphate ${ }^{4,5}$. This new theory has brought new light to the area of acid base disturbances of critically ill patients.

In critically ill subjects, the presence of metabolic acidosis is very common, particularly in septic shock patients ${ }^{6}$. The amount of metabolic acidosis measured through the SBE has been shown to be an outcome marker, when it is evaluated isolated on admission or during the first days after ICU admission? ${ }^{7}$. Its improvement has been associated with better survival. However, so far it is not clear which are the factors associa- ted with SBE variations in critically ill septic patients. In this study, we splitted septic shock patients in two groups, one group of patients who improved SBE from the day of ICU admission to the third day of ICU stay, and one group who worsened SBE in the same period. The aim of this study was to characterize the acid-base variables, according to the Stewart's theory, responsible for SBE improvement and worsening within the first three days of ICU stay.

\section{METHODS}

Data were retrieved from our prospective collected data base of a tertiary teaching seven beds intensive care unit (ICU) in São Paulo - Brazil. The period investigated was from January 2004 to May 2004. Age, gender, APACHE II score, length of stay in ICU, clinical outcome, needing for mechanical ventilation, previous diagnosis of chronic renal failure, needing for dialysis, fluids handling, general laboratorial data and infection source were collected from patients with diagnosis of septic shock daily up to the third day after ICU admission. The diagnosis of septic shock was performed according to the consensus conference criteria ${ }^{8}$.

Blood samples and fluids handling data were obtained at the end of each day. The arterial line was used to collect blood samples. Albumin, phosphate and serum $\mathrm{Mg}^{2+}$ were analyzed by colorimetric techniques, and other serum electrolytes were measured with an ion-selective electrode. Arterial blood gases and lactate were measured by the OMNI analyzer (Roche Diagnostics System, F. Hoffmann - La Roche Ltd, Basel, Switzerland) and to determine SBE value the Van Slyke method was used ${ }^{2}$. All standard formulas used to calculate physico-chemical variables are described in the appendix.

Data were considered normal using Shapiro-Wilk goodness-of-fit model, and are shown as means and standard deviation. Means between groups were compared using Student $t$ test and categorical data were compared using Fisher or Chi-square analysis as indicated. Determinants of metabolic acidosis according to Stewart's physico-chemical approach were independently correlated with variations SBE using Pearson's correlation and afterward a mathematical model was built to correlate SBE variations with the components of physico-chemical approach using a stepwise multilinear regression model. The commercially available SPSS 10.0 statistical package was used, considering $p<0.05$ as a significant level. 


\section{RESULTS}

During five months, thirty eight patients with septic shock treated according to the surviving sepsis campaign, were observed. General characteristics and infection sites of whole group are shown in table 1.

The SBE evolution was linear beyond the three first days in both groups (Figure 1 - Panel A). A slight variation around $35 \mathrm{mmol} / \mathrm{L}$ was the feature of SIDa behavior, and lactate also had a small variation. Unmeasured anions, disclosed by SIG, fall in the group who improved SBE and rise in the group who worsened SBE (Figure 1 - Panel B). Albumin levels fall in the group who worsened SBE, and initially fall in the first day rising in the second day in the group who improved SBE (Figure 1 - Panel C).

The SBE variation was individually correlated with lactate, $\mathrm{PaCO}_{2}$, creatinin and SIG (Table 4). When a stepwise multilinear regression model with SBE as a dependent variable was built, the independent variables albumin, $\mathrm{PaCO}_{2}$, SIDa, SIG and diuresis have composed an equation with the determination coefficient $\left(R^{2}\right)$ of 0.866 . Beta unstandardized coefficients of the multilinear regression model are shown in table 4. When analyzing the group of patients who SBE improved or worsened individually the results are similar.

Table 1 - General Characteristics at Admission and Infection Site of Patients

\begin{tabular}{|c|c|c|c|c|}
\hline Characteristics & $\begin{array}{l}\text { Whole Group } \\
\quad(n=38)\end{array}$ & $\begin{array}{l}\text { SBE Improved } \\
(\mathrm{n}=22)\end{array}$ & $\begin{array}{l}\text { SBE Worsened } \\
(n=16)\end{array}$ & $P$ value* \\
\hline Age (years) & $50 \pm 20$ & $48 \pm 22$ & $50 \pm 17$ & 0.742 \\
\hline Gender - females (\%) & $17(45)$ & $10(45)$ & $7(44)$ & 0.821 \\
\hline APACHE II & $23 \pm 9$ & $22 \pm 9$ & $24 \pm 16$ & 0.355 \\
\hline Death - no (\%) & $11(30)$ & $6(27)$ & $5(31)$ & 1.000 \\
\hline Mechanical ventilation - no (\%) & $31(82)$ & $17(77)$ & $14(88)$ & 0.675 \\
\hline Chronic renal failure - no (\%) & $8(21)$ & $5(23)$ & $3(19)$ & 1.000 \\
\hline Dialysis - no (\%) & $4(11)$ & $3(14)$ & $1(6)$ & 0.624 \\
\hline LOS (days)\# & $11 \pm 7$ & $11 \pm 7$ & $12 \pm 8$ & 0.743 \\
\hline Creatinin (mg/dL) & $1.9 \pm 2.2$ & $2.0 \pm 3.4$ & $1.6 \pm 1.85$ & 0.692 \\
\hline $\mathrm{pH}$ & $7.33 \pm 0.09$ & $7.32 \pm 0.09$ & $7.34 \pm 0.09$ & 0.432 \\
\hline $\mathrm{PaCO}_{2}(\mathrm{mmHg})$ & $32 \pm 9$ & $32 \pm 9$ & $33 \pm 9$ & 0.594 \\
\hline $\mathrm{SBE}(\mathrm{mEq} / \mathrm{L})$ & $-7.5 \pm 5.40$ & $-8.7 \pm 5.2$ & $-5.8 \pm 5.4$ & 0.109 \\
\hline Lactate (mmol/L) & $2.3 \pm 1.7$ & $2.4 \pm 2.1$ & $2.1 \pm 1.2$ & 0.577 \\
\hline Albumin (mg/dL) & $21.7 \pm 6.7$ & $21.2 \pm 6.7$ & $22.3 \pm 6.8$ & 0.613 \\
\hline Phosphate (mmol/L) & $0.70 \pm 0.29$ & $0.67 \pm 0.27$ & $0.74 \pm 0.32$ & 0.226 \\
\hline Hemoglobin & $9.0 \pm 1.8$ & $9.2 \pm 1.8$ & $8.8 \pm 1.9$ & 0.343 \\
\hline $\mathrm{PaCO}_{2}(\mathrm{mmHg})$ & $32 \pm 9$ & $31 \pm 9$ & $33 \pm 9$ & 0.324 \\
\hline CRP (ng/dL)" & $179 \pm 113$ & $174 \pm 99$ & $189 \pm 138$ & 0.681 \\
\hline $\mathrm{SIDa}(\mathrm{mmol} / \mathrm{L})$ & $35.0 \pm 6.7$ & $34.8 \pm 6.2$ & $34.9 \pm 7.6$ & 0.941 \\
\hline $\mathrm{SIG}(\mathrm{mmol} / \mathrm{L})$ & $11.0 \pm 7.5$ & $11.8 \pm 7.2$ & $9.9 \pm 8.1$ & 0.463 \\
\hline Chloride (mmol/L) & $106 \pm 17.3$ & $104 \pm 6.8$ & $108 \pm 6.3$ & 0.758 \\
\hline \multicolumn{5}{|l|}{ Infection Site } \\
\hline Pneumonia - no (\%) & $21(55)$ & $12(55)$ & $9(57)$ & 0.821 \\
\hline Peritonitis - no (\%) & $6(16)$ & $3(12)$ & $3(19)$ & 0.682 \\
\hline Urinary - no (\%) & $3(8)$ & $2(9)$ & $1(6)$ & 1.000 \\
\hline Mediastinitis - no (\%) & $1(3)$ & $1(5)$ & $0(0)$ & 1.000 \\
\hline Fungemia - no (\%) & $2(5)$ & $1(5)$ & $1(6)$ & 1.000 \\
\hline Soft tissue - no (\%) & $3(8)$ & $2(9)$ & $1(6)$ & 1.000 \\
\hline Catheter - no (\%) & $2(5)$ & $1(5)$ & $1(6)$ & 1.000 \\
\hline
\end{tabular}

no denotes number of patients.

${ }^{*} P$ value denotes the significance of comparisons between SBE worsened and SBE improved groups.

\# LOS denotes lenght of stay.

II CRP denotes c-reactive protein. 
Table 2 - Fluids Handling During the First Three Days

\begin{tabular}{|c|c|c|c|c|}
\hline Characteristics & $\begin{array}{l}\text { Whole Group } \\
\quad(n=38)\end{array}$ & $\begin{array}{l}\text { SBE Improved } \\
\quad(\mathrm{n}=22)\end{array}$ & $\begin{array}{l}\text { SBE Worsened } \\
(n=16)\end{array}$ & $P$ value ${ }^{*}$ \\
\hline \multicolumn{5}{|l|}{ Day 1} \\
\hline Diuresis (mL) & $1312 \pm 1462$ & $1402 \pm 1450$ & $1445 \pm 1842$ & 0.950 \\
\hline Hydric balance (mL) & $3822 \pm 4542$ & $2880 \pm 2570$ & $5313 \pm 5899$ & 0.201 \\
\hline Fluid intake (mL) & $5134 \pm 4482$ & $4281 \pm 2907$ & $6597 \pm 6390$ & 0.290 \\
\hline \multicolumn{5}{|l|}{ Day 2} \\
\hline Diuresis (mL) & $1608 \pm 1639$ & $1792 \pm 2097$ & $1437 \pm 1129$ & 0.599 \\
\hline Hydric balance (mL) & $4565 \pm 4171$ & $4306 \pm 4573$ & $4804 \pm 3937$ & 0.773 \\
\hline Fluid intake (mL) & $6172 \pm 3912$ & $6098 \pm 3921$ & $6240 \pm 4026$ & 0.930 \\
\hline \multicolumn{5}{|l|}{ Day 3} \\
\hline Diuresis (mL) & $1852 \pm 1884$ & $2192 \pm 2241$ & $1585 \pm 1584$ & 0.435 \\
\hline Hydric balance (mL) & $1761 \pm 3192$ & $645 \pm 3242$ & $2639 \pm 2974$ & 0.123 \\
\hline Fluid intake (mL) & $3613 \pm 2506$ & $2836 \pm 1785$ & $4224 \pm 2869$ & 0.174 \\
\hline \multicolumn{5}{|l|}{ First 3 days } \\
\hline Diuresis (mL) & $1630 \pm 1664$ & $1784 \pm 1920$ & $1491 \pm 1509$ & 0.433 \\
\hline Hydric balance (mL) & $3505 \pm 4092$ & $2666 \pm 3779$ & $4212 \pm 4454$ & 0.244 \\
\hline Fluid intake (mL) & $5084 \pm 3765$ & $4450 \pm 3249$ & $5703 \pm 4274$ & 0.142 \\
\hline
\end{tabular}

no denotes number of patients.

${ }^{*} \mathrm{P}$ value denotes the significance of comparisons between SBE worsened and SBE improved groups.

Table 3 - Vasopressors and Inotropics Used

\begin{tabular}{|c|c|c|c|c|}
\hline Characteristics & $\begin{array}{l}\text { Whole Group } \\
(n=38)\end{array}$ & $\begin{array}{l}\text { SBE Improved } \\
(\mathrm{n}=22)\end{array}$ & $\begin{array}{l}\text { SBE Worsened } \\
(n=16)\end{array}$ & $P$ value ${ }^{\star}$ \\
\hline Norepinephrine - no (\%) & $38(100)$ & $22(100)$ & $16(100)$ & \\
\hline Mean maximal dosis $(\mu \mathrm{g} / \mathrm{kg} / \mathrm{min})$ & $0.81 \pm 1.68$ & $0.96 \pm 1.89$ & $0.69 \pm 1.35$ & 0.270 \\
\hline Dobutamine - no (\%) & $33(87)$ & $19(86)$ & $14(88)$ & 0.831 \\
\hline Mean maximal dosis ( $\mu \mathrm{g} / \mathrm{kg} / \mathrm{min})$ & $13.7 \pm 6.1$ & $13.1 \pm 5.9$ & $14.1 \pm 6.2$ & 0.617 \\
\hline
\end{tabular}

no denotes number of patients.

${ }^{*} \mathrm{P}$ value denotes the significance of comparisons between SBE worsened and SBE improved groups.

Table 4 - Linear and Multilinear Correlation between SBE and Metabolic Acidosis Determinant Variables

\begin{tabular}{|c|c|c|c|c|}
\hline & Single Correlation & & Stepwise Multilinear Regression * & \\
\hline Variables & Pearson Coefficient & $P$ value & Beta Unstandardized Coefficient & $P$ value \\
\hline Lactate & -0.211 & 0.024 & - & - \\
\hline Albumin & -0.059 & 0.534 & -34.5 & $<0.001$ \\
\hline $\mathrm{PaCO}_{2}$ & 0.364 & $<0.001$ & -0.2 & $<0.001$ \\
\hline Creatinin & -0.346 & $<0.001$ & - & - \\
\hline SIG & -0.368 & $<0.001$ & -1.2 & $<0.001$ \\
\hline Diuresis" $\#$ & 0.044 & 0.711 & 0.03 & 0.014 \\
\hline C-reactive protein & -0.242 & 0.105 & - & - \\
\hline Hydric balance & -0.101 & 0.390 & - & - \\
\hline Fluids received" & -0.090 & 0.441 & - & - \\
\hline
\end{tabular}

*The final model with five variables resulted in a determination coefficient $\left(R^{2}\right)$ of 0.866 . The inclusion criteria of the model was an $F$ probability of 0.05 and exclusion criteria was an F probability of 0.1 . C-reactive protein was not included in the initial multilinear model due to a high collinearity with albumin (Pearson coefficient of $0.550)$.

\#Numbers respective to each day. 




Figure 1 - Panel A shows the Evolution of SBE during the Three First Days. Panel B shows the Evolution of SIDa, SIG and Lactate. Panel C shows the Evolution of Albumin.

\section{DISCUSSION}

In our study, we have shown that in septic shock patients the SBE variation during the first three days of ICU stay is weakly correlated to SIG, lactate, creatinin and $\mathrm{PaCO}_{2}$ when individually analyzed. Analyzing concomitantly those independent variables, we built a mathematical model with a stepwise multilinear regression composed by SIDa, SIG, $\mathrm{PaCO}_{2}$, albumin and diuresis that resulted in a $R^{2}$ coefficient of 0.866 to determine SBE variations.

Since the description of base excess in $1960^{1}$, it has been largely used in the clinical practice to disclose and measure metabolic acidosis ${ }^{3,4,9}$. However, base excess or its clinical derivation SBE are limited to detect true metabolic acidosis in adult critically ill patients and in pediatric cardiac postoperative ${ }^{10,11}$. This limitation has been ascribed to hypoalbuminemia, which can cause metabolic alkalosis hiding or attenuating any kind of installed metabolic acidosis ${ }^{11}$. In spite of the apparent limited information's given by the SBE, low values of SBE at the admission to ICU has been associated with poor outcome $e^{12-15}$, and in the same way the improvement of SBE by the third day after the ICU admission has been independently correlated with better progno$\mathrm{sis}^{7}$. In the hemodynamic early goal directed therapy study performed by Rivers et al. ${ }^{16}$ to severe sepsis and septic shock patients, the interventional group improved SBE close to normal values by the third day, starting from very low initial values. Those characteristics turn SBE an important clinical physiological tool to be used in the modern ICU.

It is interesting to note that among our patients there were not admission characteristics that have identified the subjects who could improve or worse SBE until the third day. The amount and quality of fluids used in resuscitation of shock can, theoretically, be related to acid base state modifications ${ }^{3,9}$. In our study, the amount of fluids used in both groups were similar (Table 2) and the standard fluid used was ringer lactate, in this way, the great acid base derangements expected using crystalloids would be SIDa variations, by contrast, our finding point out to SIG as a correlate with SBE in the univariate analysis (Table 4). SIG actually quantify unmeasured anions ${ }^{3,5}$, and it can be raised by colloids ${ }^{3}$, which were not used in our patients. Other possible sources of SIG acidosis in septic shock patients are: 1. mitochondrial dysfunction, which can be secondary to oxygen deprivation ${ }^{17}$ or inflammatory mediators ${ }^{18}$, and 2. renal dysfunction by reducing clearance of non volatile 
acids ${ }^{19}$. Currently, there are some investigations about the unmeasuble anions components of SIG acidosis, and some metabolic intermediates of Krebs' cycle as isocitrate, $\alpha$-ketoglutarate and malate has been associated with SIG acidosis ${ }^{20}$, although, the definitive list of endogenous anions that can cause metabolic SIG acidosis in sepsis and shock states is far from complete ${ }^{21}$. There are some evidences that SIG acidosis is correlated with outcome ${ }^{13,14}$, and it is additive with prognostic information of serum lactate level ${ }^{12}$.

Serum lactate level is a well known cause of metabolic acidosis in critically ill patients ${ }^{22}$, but its clinical and physiological importance has been shared with other unmeasured anions ${ }^{12,14}$. It has been associated with oxygen deprivation, inflammation and hepatic dysfunction $^{22}$. Our correlation finding between SBE and lactate is physiologically rational (Table 4$)^{9}$, and the lactate exclusion of the final stepwise regression model can be explained by the fact that the unmeasured anions calculated by SIG physiologically behave quite similar to lactate ${ }^{17,20}$, likewise, in the mathematical model the inclusion of lactate could not be of great importance in the modification of $\mathrm{F}$ probability statistics, and this fact is an acquard reflection of clinical association among SIG, SBE and lactate li, $^{12,20}$.

Creatinin was other finding associated with SBE variation. Low renal clearance is associated with increments in $\mathrm{SIG}^{19}$, but in our patients it is hard to affirm that SIG acidosis has been caused by low renal clearance or SIG acidosis has been epiphenomena which has resulted from the critical illness and multiorgan dysfunction ${ }^{18,23}$. Diuresis is an immediate reflection of renal clearance and can disclose renal impairment earlier than creatinin elevations ${ }^{24}$. Otherwise, few patients can present oliguria without elevations of creatinin, but acidosis will be present only if renal failure is present ${ }^{19}$. In this way, we can understand why diuresis was associated with SBE variations only in the mathematical multilinear mode ${ }^{25}$. Partial pressure of carbon dioxide was positively associated with SBE variations as expected by the mathematical calculus using the Van Slyke equation, where bicarbonate concentration is one of the independent variables besides $\mathrm{pH}^{2}$. Thus, from the stoichiometric point of view, one can expect that rising $\mathrm{PaCO}_{2}$ the bicarbonate and then SBE will also rise ${ }^{1}$. Otherwise, in our multilinear mathematical model, an interesting finding was the negative correlation of $\mathrm{PaCO}_{2}$ and SBE variations, contrasting with the single correlation. This finding can represent the clinical status of patients, where higher the severity of the disease, higher the probability to be on mechanical ventilation, reflecting in low SBE due to the severity of disease and $\mathrm{PaCO}_{2}$ dependent of mechanical ventilation strategy. In this way, we would like to stress that fourteen patients $(37 \%)$ accomplished acute respiratory distress syndrome (ARDS) criteria of consensus conference ${ }^{26}$, and in our patients the open lung approach with permissive hypercapnia has been used to ventilate ARDS patients ${ }^{27}$. The advantage of the mathematical stepwise multilinear regression in this case was the representation of SBE as a multicomponent tool, reproducing the complex clinical acid base environment ${ }^{25}$.

Albumin and phosphate have been considered as the main weak acids in organic systems that are responsible for acid base modulation ${ }^{10,28-30}$. Hypoalbuminemia is a frequent finding in critically ill patients and also in our patients (Table 1, Figure 2), being an important source of metabolic alkalosis and $\mathrm{pH}$ and SBE neutralization in this setting as we can observe in table 4, in the mathematical model ${ }^{11}$.

Funk et al. ${ }^{31}$ studied the acid base behavior in a general ICU population, showing chloride and SIDa as the main determinants of acid base behavior. By contrast, in septic shock patients, according to our findings the acidosis variation measured by the SBE results from a complex situation, and SIDa was important only in the mathematical multilinear model when analyzed together with other components associated with metabolic acidosis.

We would like to stress that the physico-chemical approach is not superior to the traditional approach at bedside to diagnose acid-base derangements ${ }^{32}$. However, this methodology allows the quantification of respiratory and / or metabolic shifts to statistical measurement. In this way, we have used the physico-chemical approach in our study.

In conclusion, variations of metabolic acidosis measured through the SBE in septic shock patients when analyzed until the third day after ICU admission, is resultant of interaction of several independent determinants as $\mathrm{PaCO}_{2}$, diuresis, SIG, SIDa and albumin.

\section{APPENDIX - STANDARD FORMULAS}

1. Standard base excess (Van Slyke's equation) $\left(\mathrm{SBE}_{\mathrm{vs}}\right)$ $(\mathrm{mEq} / \mathrm{L})=0.9287 \times\left(\mathrm{HCO}_{3}-24.4+14.83 \times[\mathrm{pH}-7.4]\right)$ 2. Apparent strong ion difference $\left(\mathrm{SID}_{\mathrm{a}}\right)(\mathrm{mEq} / \mathrm{L})=\mathrm{Na}^{+}+$ $\mathrm{K}^{+}+\mathrm{Ca}^{2+}+\mathrm{Mg}^{2+}-\mathrm{Cl}^{-}$- Lactate

3. Effective strong ion difference $\left(\mathrm{SID}_{\mathrm{e}}\right)(\mathrm{mEq} / \mathrm{L})=2.46$ 
$\times 10^{-8} \times \mathrm{PCO}_{2} / 10^{-\mathrm{pH}}+[$ albumin $(\mathrm{g} / \mathrm{dL})] \times(0.123 \times \mathrm{pH}-$ $0.631)+[\mathrm{phosphate}(\mathrm{mg} / \mathrm{dL}) / 3 \times(\mathrm{pH}-0.469)]$

4. SIG $(\mathrm{mEq} / \mathrm{L})=\mathrm{SIDa}-\mathrm{SIDa}$

5. Albumin $(\mathrm{mEq} / \mathrm{L})=10 \times$ Albumin $(\mathrm{g} / \mathrm{dL}) \times(0.123 \times$ $\mathrm{pH}-0.631)$

6. Inorganic phosphate $(\mathrm{Pi})(\mathrm{mEq} / \mathrm{L})=\left(\mathrm{PO}_{4}(\mathrm{mg} / \mathrm{dL}) \times\right.$ $10 / 30,97) \times(0.309 \times \mathrm{pH}-0.469)$

7. The unit of all strong ions was $\mathrm{mEq} / \mathrm{L}$

\section{REFERENCES}

01. Astrup P, Jorgensen K, Andersen OS et al - The acid-base metabolism. A new approach. Lancet, 1960;1:1035-1039.

02. Morgan TJ, Clark C, Endre ZH - Accuracy of base excess--an in vitro evaluation of the Van Slyke equation. Crit Care Med, 2000;28:2932-2936.

03. Kellum JA - Clinical review: reunification of acid-base physiology. Crit Care, 2005;9:500-507.

04. Corey HE - Bench-to-bedside review: Fundamental principles of acidbase physiology. Crit Care, 2005;9:184-192.

05. Stewart PA - Modern quantitative acid-base chemistry. Can J Physiol Pharmacol, 1983;61:1444-1461.

06. MacKenzie IM - The haemodynamics of human septic shock. Anaesthesia, 2001;56:130-144.

07. Palma LC, Ferreira GF, Amaral ACKB et al - Acidosis and mortality in severe sepsis and septic shock evaluated by base excess variation. Crit Care, 2003;7(Suppl3):P39.

08. Bone RC, Sibbald WJ, Sprung CL - The ACCP-SCCM consensus conference on sepsis and organ failure. Chest, 1992;101:1481-1483.

09. Gunnerson KJ - Clinical review: the meaning of acid-base abnormalities in the intensive care unit part I - epidemiology. Crit Care, 2005;9:508-516.

10. Murray DM, Olhsson V, Fraser JI - Defining acidosis in postoperative cardiac patients using Stewart's method of strong ion difference. Pediatr Crit Care Med, 2004;5:240-245

11. Fencl V, Jabor A, Kazda A et al - Diagnosis of metabolic acid-base disturbances in critically ill patients. Am J Respir Crit Care Med, 2000;162:2246-2251.

12. Smith I, Kumar P, Molloy S et al - Base excess and lactate as prognostic indicators for patients admitted to intensive care. Intensive Care Med, 2001;27:74-83.

13. Balasubramanyan N, Havens PL, Hoffman GM - Unmeasured anions identified by the Fencl-Stewart method predict mortality better than base excess, anion gap, and lactate in patients in the pediatric intensive care unit. Crit Care Med, 1999;27:1577-1581.

14. Kaplan LJ, Kellum JA - Initial pH, base deficit, lactate, anion gap, strong ion difference, and strong ion gap predict outcome from major vascular injury. Crit Care Med, 2004;32:1120-1124.

15. Dondorp AM, Chau TT, Phu NH et al - Unidentified acids of strong prognostic significance in severe malaria. Crit Care Med, 2004;32:1683-1688.

16. Rivers E, Nguyen B, Havstad S et al - Early goal-directed therapy in the treatment of severe sepsis and septic shock. $\mathrm{N}$ Engl $\mathrm{J}$ Med, 2001;345:1368-1377.

17. Kellum JA, Bellomo R, Kramer DJ et al - Hepatic anion flux during acute endotoxemia. J Appl Physiol, 1995;78:2212-2217.

18. Brealey D, Brand M, Hargreaves I et al - Association between mitochondrial dysfunction and severity and outcome of septic shock. Lancet, 2002;360(9328):219-223.

19. Rocktaeschel J, Morimatsu H, Uchino S et al - Acid-base status of critically ill patients with acute renal failure: analysis based on Stewart-Figge methodology. Crit Care, 2003;7:R60.

20. Forni LG, McKinnon W, Lord GA et al - Circulating anions usually associated with the Krebs cycle in patients with metabolic acidosis. Crit Care 2005;9:R591-R595.

21. Bowling FG, Morgan TJ - Krebs cycle anions in metabolic acidosis. Crit Care, 2005;9(5):E23.

22. De Backer D - Lactic acidosis. Intensive Care Med, 2003;29:699-702.

23. Singer M, De Santis V, Vitale D et al - Multiorgan failure is an adaptive, endocrine-mediated, metabolic response to overwhelming systemic inflammation. Lancet, 2004;364(9433):545-548

24. Bellomo R, Ronco C, Kellum JA et al - Acute renal failure - definition, outcome measures, animal models, fluid therapy and information technology needs: the Second International Consensus Conference of the Acute Dialysis Quality Initiative (ADQI) Group. Crit Care, 2004;8:R204-R212.

25. Marill KA - Advanced statistics: linear regression, part II: multiple linear regression. Acad Emerg Med, 2004;11:94-102.

26. Bernard $\mathrm{GR}$, Artigas $\mathrm{A}$, Brigham $\mathrm{KL}$ et al - The American-European Consensus Conference on ARDS. Definitions, mechanisms, relevant outcomes, and clinical trial coordination. Am J Respir Crit Care Med, 1994;149:818-824.

27. Amato MB, Barbas CS, Medeiros DM et al - Effect of a protective-ventilation strategy on mortality in the acute respiratory distress syndrome. $\mathrm{N}$ Engl J Med, 1998;338:347-354.

28. Figge J, Jabor A, Kazda A et al - Anion gap and hypoalbuminemia. Crit Care Med, 1998;26:1807-1810.

29. Figge J, Mydosh T, Fencl V - Serum proteins and acid-base equilibria: a follow-up. J Lab Clin Med, 1992;120:713-719.

30. Figge J, Rossing $\mathrm{TH}$, Fencl $\mathrm{V}$ - The role of serum proteins in acid-base equilibria. J Lab Clin Med, 1991;117:453-467.

31. Funk GC, Doberer D, Heinze G et al - Changes of serum chloride and metabolic acid-base state in critical illness. Anaesthesia, 2004;59:1111-1115

32. Dubin A, Menises MM, Masevicius FD et al - Comparison of three different methods of evaluation of metabolic acid-base disorders. Crit Care Med, 2007;35:1264-1270. 